\title{
O12 - Specific lgE levels for goat's and sheep's milk after successful oral immunotherapy to cow's milk in children
}

\author{
Liseth Villafana ${ }^{1 *}$, Soledad Terrados ${ }^{1}$, Belen De la Hoz ${ }^{1}$, Mónica Rodriguez², Ana De Andrés ${ }^{1}$ \\ From 3rd Pediatric Allergy and Asthma Meeting (PAAM) \\ Athens, Greece. 17-19 October 2013
}

\section{Introduction}

Cow's milk (CM) oral immunotherapy has proven to be effective as a treatment for persistent CM allergy. Allergic reactions to goat and sheep cheeses have been described in almost $25 \%$ of patients desensitised to CM, indicates that immunotherapy is specific for each milk.

\section{Objectives}

To describe changes of goat's IgE and sheep's IgE in patients who tolerated CM after a CM oral immunotherapy.

\section{Methods}

24 children aged between 4 and 13 who achieved tolerance to milk after CM immunotherapy were included. Specific IgE to cow's caseine, sIgE to whole goat's milk and sIgE to whole sheep's milk at baseline and at 24 months follow up were analised (CAP-Phadia). The patientes were classified in two groups: high risk (17 patients) and low risk (7 patients) based on the premedication need, number of adverse reactions and time to achieve a complete tolerance to $\mathrm{CM}$.

\section{Results}

The median of Specific IgE to CM casein, goat's whole milk, sheep's whole milk a baseline were $24.3 \mathrm{KU} / \mathrm{L}$, $31.2 \mathrm{KU} / \mathrm{L}$ and $27.4 \mathrm{KU} / \mathrm{L}$ and $9.5 \mathrm{KU} / \mathrm{L}, 16.9 \mathrm{KU} / \mathrm{L}$ and $17.3 \mathrm{KU} / \mathrm{L}$ after 24 months of follow up ( $<<0,05)$.In the high risk patients the median of Specific IgE to CM casein, goat's whole milk, sheep's whole milk were $33.7 \mathrm{KU} / \mathrm{L}, 43.7 \mathrm{KU} / \mathrm{L}$ and $37.1 \mathrm{KU} / \mathrm{L}$ at baseline and $13.1 \mathrm{KU} / \mathrm{L}, 23.9 \mathrm{KU} / \mathrm{L}$ and $23.6 \mathrm{KU} / \mathrm{L}$ after 24 of follow up $(\mathrm{p}<\mathrm{0}, \mathrm{o} 5)$. In contrast, in the low risk group the specific

${ }^{1}$ Ramón y Cajal Hospital, Madrid, Spain

Full list of author information is available at the end of the article
IgE to CM casein, goat's whole milk, sheep's whole milk did not shown a significant decrease after 24 of follow up. 4 patients showed a different patron referred to IgEgoat's milk and IgE-sheep's milk compared with CM, independently of risk group.

\section{Conclusions}

We found a decrease of IgE levels to whole goat's and sheep's milk after oral immunotherapy to CM.

Authors' details

${ }^{1}$ Ramón y Cajal Hospital, Madrid, Spain. ${ }^{2}$ San Carlos Clinic Hospital, Madrid, Spain.

Published: 28 February 2014

doi:10.1186/2045-7022-4-S1-012

Cite this article as: Villafana et al.: 012 - Specific lgE levels for goat's

and sheep's milk after successful oral immunotherapy to cow's milk in children. Clinical and Translational Allergy 2014 4(Suppl 1):012.

Submit your next manuscript to BioMed Central and take full advantage of:

- Convenient online submission

- Thorough peer review

- No space constraints or color figure charges

- Immediate publication on acceptance

- Inclusion in PubMed, CAS, Scopus and Google Scholar

- Research which is freely available for redistribution

Submit your manuscript at www.biomedcentral.com/submit 